the National Institute of Agricultural Botany, Cambridge. The president, Mr. A. E. Birks, stated in his address that members are continuing to avail themselves of the facilities afforded by the Association, and during the year a number of interesting experiments were carried out by members working together. In one case, tests were made on a particularly difficult sample of asparagus kale in an endeavour to arrive at an equable result. The wide divergence in results obtained proves that there still remain factors governing the germination of this seed which are not fully understood. Mr. Harding gave an address on the comparison of soil and laboratory tests. He considers that soil tests properly carried out are of real value in estimating the maximum percentage of plantlets that can be obtained under field conditions. In some instances, when working upon new seeds, results from the laboratory and the soil tests are identical : greater differences occur when old seed is being tested. Finally, soil tests are certainly helpful when made in conjunction with the laboratory, as they assist in revealing discrepancies. The following officers were elected for the coming year : President, Mr. E. B. Wallace; Vice-President, Mr. A. E. Birks ; Hon. Secretary and Treasurer, Mr. F. H. G. Neale, "Emmandee", Hawthorn Gardens, Reading.

\section{Annual Report of the Ministry of Health}

THE thirteenth Annual Report of the Ministry of Health, 1931-1932 (H.M. Stationery Office. 5s. net), recently issued, is in the main a record of the more important business transacted by the Ministry during the year, and does not cover matters of routine or detail, the Annual Report of the Chief Medical Officer of the Ministry being published separately as in previous years. Allusion is made to the British Postgraduate Hospital and Medical School, now in process of formation, for which a grant of $£ 250,000$ had been previously contemplated, but for which Parliament will now be invited to contribute a maximum grant of $£ 100,000$ in view of the exigencies of the time. The National Radium Trust has made further purchases of radium, and now owns a little more than $17 \mathrm{gm}$. Local authorities have been active during the year in the sewering of their areas, and loans sanctioned during the year amounted to nearly $7 \frac{3}{4}$ million pounds. Other subjects dealt with in the Report fall under the main heads of public health, housing and town planning, local government and finance, poor law, and national health insurance.

\section{Library of Educational Films}

THE Empire Marketing Board has published a new edition of its film library catalogue, and copies are obtainable free on request from the Board, 2 Queen Anne's Gate Buildings, London, S.W.1. A great variety of films illustrating different aspects of scenery, natural history, and economic activity is now available. These cover most parts of the Empire. An important addition to the list is a series of class-room films, which are intended for the use of teachers rather than for general circulation. There are about forty of these films, some of which are travel surveys, while others deal with such subjects as canals, irrigation, cotton, wool, water power, or social life. All the films are available free for approved displays at which there is no charge for admission. Carriage must be paid by the borrower.

\section{Cancer Mortality in the United States}

Deaths from cancer have increased alarmingly throughout the United States of America in the past year and a half, in the face of extremely favourable general health conditions. Science Service, of Washington, D.C., notes, under date Aug. 9, that figures compiled by the Metropolitan Life Insurance Company upon its industrial policy holders show a rise of $\mathbf{7 \cdot 4}$ per cent in 1931, and for the first half of 1932, a further rise of 9.5 per cent over the rate for the like part of last year : the average rise in the period 1919 1930 was 1.5 per cent a year. Although official mortality statistics are not yet available for any large part of the country, the provisional reports are said to substantiate the Metropolitan figures.

\section{Announcements}

Mr. Wiefred TrotTer has been appointed a member of the Advisory Committee on the Administration of the Cruelty to Animals Act, 1876, in succession to Sir Arthur Keith, who has resigned.

DR. JAMES LAw BRownLIE has been appointed by the Secretary of State for Scotland chief medical officer of the Department of Health for Scotland in succession to the late Dr. John Parlane Kinloch.

THE annual exhibition of the Professional Photographers' Association was opened at the Princes Galleries, Piccadilly, London, W., on Sept. 5, and will remain open until Sept. 29. The exhibits comprise industrial photography as well as portrait work.

Dr. Harold Moore, who has for many years been director of metallurgical research at the Research Department, Woolwich, has been appointed, as from Oct. 1, director of the British Non-Ferrous Metals Research Association, to succeed Dr. R. S. Hutton, who has been elected to the new Goldsmiths professorship of metallurgy at the University of Cambridge.

Applications are invited for the following appointments, on or before the dates mentioned :-A lecturer in mechanical engineering at the Swindon Technical College-The Director of Education, Education Office, Clarence Street, Swindon (Sept. 24). Inspectors for the purposes of the Diseases of Animals Act, 18941927, in the Ministry of Agriculture and Fisheries-The Secretary, Ministry of Agriculture and Fisheries, 10 Whitehall Place, S.W.1 (Sept. 26). An assistant lecturer in engineering and a lecturer in production engineering at the County Technical College, Wednesbury-The Director of Education, County Education Offices, Stafford (Sept. 29). A lecturer in pure mathematics at the Wimbledon Technical College -The Principal, Wimbledon Technical College, Gladstone Road, S.W.19. A science master (chiefly physics) at the Prince of Wales' Indian Military College, Dehra Dun, United Provinces, India-The Secretary, Military Department, India Office, London, S.W.1.

$$
\text { No. 3281, VoL. 130] }
$$

